\title{
TITLE:
}

\section{ON SOME OPHIURANS FROM KII AND VICINITIES WITH DESCRIPTION OF A NEW SPECIES}

$\operatorname{AUTHOR(S):~}$

Murakami, Shiro

\section{CITATION:}

Murakami, Shiro. ON SOME OPHIURANS FROM KII AND VICINITIES WITH DESCRIPTION OF A NEW SPECIES. PUBLICATIONS OF THE SETO MARINE BIOLOGICAL LABORATORY 1963,

11(2): 171-184

ISSUE DATE:

1963-12-31

URL:

http://hdl.handle.net/2433/175345

RIGHT: 


\title{
ON SOME OPHIURANS FROM KII AND VICINITIES WITH DESCRIPTION OF A NEW SPECIES ${ }^{13}$
}

\author{
SHIRO MURAKAMI \\ Seikai Regional Fisheries Research Laboratory \\ Nagasaki, Japan \\ With one Text-figure
}

Several years ago I fortunately received a littoral and sublittoral Ophiuran material from Dr. T. HABE, former member of the Seto Marine Biological Laboratory of Kyoto University, which was collected by him and his colleague, Mr. S. SaKaguchi in the vicinity of Kii Peninsula. As a result of my research on them, I could distinguish no less than twenty-four species among them, one belonging to a new form. The Ophiurans dealt with are listed as follows:

Order GNATHOPHIURIDA

Family Amphiuridae

Subfamily Ophiactinae

1. Ophiactis modesta Brock

2. Ophiactis profundi LütKen et MORTENSEN

3. Ophiactis savignyi (Müller et TrOSCHEL)

4. Ophiopholis brachyactis $\mathrm{C}_{\mathrm{LARK}}$

Subfrmily Amphiurinae

5. Amphioplus asterictus $\mathrm{C}_{\mathrm{LARK}}$

6. Amphioplus miyadii MURAKamI

7. Amphichilus trichoides Matsumoto

8. Amphioplus japonicus (Matsumoto)

9. Amphipholis japonica Matsumoto

Family Ophiothricidae

10. Ophiothrix koreana DUNCAN

11. Ophiothrix marenzelleri KOEHLER

12. Ophiotrichoides nereidina (LAMARCK)

Order CHILOPHIURIDA

Family Ophiuridae

1) Contributions from the Seto Marine Biological Laboratory, No. 402.

Publ. Seto Mar, Biol. Lab., XI (2), 1963. (Article 13) 
Subfamily Ophiurinae

13. Stegophiura sculpta (DUNCAN)

14. Stegophiura sladeni (DuNCAN)

15. Stegophiura sterea (CLARK)

16. Ophiura kinbergi (LJUNGMAN)

Subfamily Ophiolepidinae

17. Ophiomusium simplex LymaN

18. Ophiomusium trychnum $\mathrm{C}_{\mathrm{LARK}}$

19. Ophiozonella longispina (CLARK)

20. Ophioplocus japonicus $\mathrm{C}_{\mathrm{LARK}}$

Family Ophiodermatidae

Subfamily Ophiodermatinae

21. Ophiarachnella gorgonia (MÜLLER et TROSCHEL)

Family Ophiocomidae

Subfamily Ophiocominae

22. Ophiocoma brevipes Peters

23. Ophiomastix mixta LÜTKEN

Subfamily Ophiopsilinae

24. Ophiopsila squamifera sp. nov.

Among these Ophiurans, Ophiactis modesta, Ophiactis savignyi, Amphipholis japonica, Ophiothrix koreana, Ophiotrichoides nereidina, Stegophiura sculpta, Stegophiura sladeni, Ophiomusium simplex, Ophiozonella longispina, Ophioplocus japonicus, Ophiarachnella gorgonia, Ophiocoma brevipes, Ophiomastix mixta and Ophiopsila squamifera seem to be newly described from the districts. Further, Ophiactis savignyi is an intertropical species and widely distributed in the Indo-Pacific and Atlantic, reaching as far as Misaki northwards in the Japanese waters. Ophiotrichoides nereidina, Ophiura kinbergi, Ophiarachnella gorgonia and Ophoicoma brevipes range from the Indian Ocean to the Pacific Ocean, O. kinbergi being reported from Otaru northwards, O. nereidina and $O$. gorgonia from Misaki, and $O$. brevipes from South Izu. Ophiactis modesta, Ophiactis profundi, Amphioplus japonicus, Ophiothrix koreana, Stegophiura sculpta, Ophiomusium simplex and Ophiomastix mixta occur in the Pacific Ocean including the Malaysian waters, $O$. koreana having known northern limit at Hakodate Bay, $O$. profundi at off Tsugaru Channel, Sea of Japan, O. japonicus at Mutsu Bay, O. mixta at the Gulf of Tokyo, O. modesta at Misaki, S. sculpta at South Izu and O. simplex at southwest of the Goto Islands. The remainder have only been recorded from the Japanese waters, but Ophioplocus japonicus extends its distribution as far as Hong Kong southwards.

Before going further, I must express my gratitude to Messrs. T. HABE and S. SAKAGUCHI for their kindness in sending me a valuable material. 


\section{Systematics}

\section{Order GNATHOPHIURIDA}

Family Amphiuridae

Subfamily Ophiactinae

1. Ophiactis modesta BROCK

BRock, 1888, p. 482 ; DöDerlein, 1896, p. 285, pl. XIV, fig. 1, pl. XV, figs. 5-5b ; Matsumoto, 1917, p. 156, fig. 38.

Locality.-Seto, Kii, 1943 ; one specimen.

Distribution.-Misaki (Matsumoto). Tomioka, Amakusa (Murakami). Palao (Murakami). Amboina (Brock). Thursday Islands (Döderlein).

\section{Ophiactis profundi LÜTKEN et MORTENSEN}

Ophiactis profundi: LütKen et MorTensen, 1899, p. 140, pl. VI, figs. 4-6; KoehleR, 1922, p. 192, pl. LXIII, fig. 8.

Ophiactis pteropoma: CLARK, 1911, p. 134, fig. 50 ; MATsumoto, 1917, p. 154, pl. III, fig. 9.

Locality.-Off Minabe, Kii, 1943 ; one specimen.

Distribution.--Uraga Channel (Clark). Misaki (Matsumoto). Off Hiro Misaki Light (Clark) ${ }^{1}$. Off Kii (Clark). Off Tsugaru Channel, Sea of Japan (Clark). Pacific, including Malaysian waters.

At first Clark described Ophiactis pteropoma as a distinct species from $O$. profundi. MAтsumoto (1917) noted that O. pteropoma was extremely close to O. profundi, from which it only differed in having the arm spines unequal instead of being subequal. KoeHLer (1922) asserted that it was impossible to maintain a distinction between $O$. pteropoma and $O$. profundi, because the only difference which he could find between the descriptions and figures of the two species consisted in relative length of the dorsal arm plate, and he united $O$. pteropoma with $O$. profundi as synonym. Further, CLARK (1918) was convinced that the species Ophiactis plana, O. flexuosa, O. perplexa, O. profundi and $O$. brachygenys belonged to a single species. But Mortensen (1924) expressed a discrepancy to it, giving the remarks on their distinctness, and took KoEHLER's proposition as probable. The specimen at hand, which measures $6 \mathrm{~mm}$ across the disk, is of pteropoma-type. The arm spines are unequal, among which the dorsal one is the largest, but is much less than twice as long as the ventral one which is a trifle longer than a joint.

1) Judging from the position, probably Hino Misaki Light, Kii. 


\section{Ophiactis savignyi (MưlLER et TROSCHEL)}

Ophiolepis savignyi: MÜLler. et TrOSCHEL, 1842, p. 95.

Ophiactis savignyi: LJUNGMAN, 1867, p. 323 ; LyMAN, 1882, p. 115 ; MATSUMOTo, 1917, p. 158, fig. 39 .

Ophiactis krebsii: LUTKEN, 1856, p. 12.

Ophiactis virescens: LÜTKEN, ditto, p. 24.

Ophiolepis sexradia: GRUBE, 1857, p. 343.

Ophiactis reinhardtii: LÜTKEN, 1859, p. 161, pI. III, fig. 7 .

Ophiactis incisa: MARTENS, 1870, p. 248.

Ophiactis brocki: LORIOL, 1893, p. 401, pl. XIV, fig. 1.

Localities.-Sirahama, Kii, 1943 ; five specimens. Seto, Kii, 1943 ; two specimens.

Distribution.--Misaki (Matsumoto). Izu (Murakami). Tomioka, Amakusa (Murakami). Korean Seas (Duncan). Indo-Pacific. Atlantic.

\section{Ophiopholis brachyactis CLARK}

Clark, 1911, p. 117, fig. 44 ; Matsumoto, 1917, p. 163, fig. 42.

Locality.-Off Minabe, Kii, 1943; one specimen.

Distribution. -Uraga Channel (Clark, Matsumoto). Off Misaki (Matsumoto). Sagami Sea (Clark, Murakami). Suruga Gulf (Clark). Off Kii (Clark). Off east coast (C $\mathrm{C}_{\mathrm{LARK}}$ ). Off Kagoshima Gulf (CLARK). Eastern Sea (CLARK). Sea of Japan ( $\left.\mathrm{C}_{\mathrm{LARK}}\right)$. Off Ando Zaki (C $\left.\mathrm{C}_{\mathrm{LARK}}\right)$.

\section{Subfamily Amphiurinae}

\section{Amphioplus asterictus $\mathrm{C}_{\mathrm{LARK}}$}

Amphioplus asterictus: ClaRK, 1915, p. 252, pl. VII, figs. 9-11.

Amphioplus diacritus: MURAKAMI, 1943c, p. 225, fig. 1.

Localities.-Hôza Bay, Ise, mud bottom, 1943; one specimen. Kowa Bay, Ise, mud bottom, 1943 ; one specimen.

Distribution.-Gulf of Tokyo (CLARK). Gokasyo Bay (Murakami). Matoya Bay (Murakami).

As compared with Clark's original description and figures of Amphioplus asterictus, the author's $A$. diacritus reveals a close resemblance to it in many features. Only differences which the author can find between them are that disk scales of $A$. asterictus is somewhat coarser than those of $A$. diacritus, and that the two proximal sides of oral shield of the former are longer than the distal ones, but their contrast is not so distinct in the latter. Such differences, 
however, may not be of specific value. Therefore, it seems to be better to unite $A$. diacritus with $A$. asterictus.

\section{Amphioplus miyadii MURAKAMI}

Murakami, 1943c, p. 227, fig. 2.

Localities.-Kanzaki, Ise, mud bottom, 1943 ; two specimens. Kowa Bay, Ise, mud bottom, 1943 ; three specimens.

Distribution.-Ago Bay (MurakamI). Gokasyo Bay (Murakami). Beppu Bay (Murakami). Hakata Bay (Murakami). Nanao Bay (Murakami).

\section{Amphichilus trichoides Matsumoto}

Matsumoto, 1917, p. 175, fig. 45; Murakami, 1934c, p. 229.

Localities.-Kanzaki, Ise, mud bottom, 1943 ; eight specimens. Hôza Bay, Ise, mud bottom, 1943 ; ten specimens. Kowa Bay, Ise, mud bottom, 1943 ; two specimens.

Distribution.-Sagami Sea? (Matsumoto). Ago Bay (Murakami). Gokasyo Bay (Murakami). Matoya Bay (Murakami). Nanao Bay (Murakami).

\section{Amphioplus japonicus (Matsumoto)}

Ophiophragms japonicus: MAтsumoтo, 1915 , p. $70 ;-, 1917$, p. 183, fig. 48, pl. IV, fig. $3 ;--, 1941$, p. 333 , fig. 2 .

Amphioplus japonicus: ClaRK, 1918, p. 271.

Localities.-Kanzaki, Ise, mud bottom, 1943; two specimens. Hôza Bay, Ise, mud bottom, 1943; two specimens. Tanabe Bay, Kii, mud bottom, 1943; two specimens.

Distribution.-Mutsu Bay (Matsumoto). Off Oginohama, Rikuzen (MAtsuмото). Enoura, Suruga (Matsumoto). Mikawa Bay (Murakami). Ise Bay (Murakami). Ago Bay (Murakami). Matoya Bay (Murakami). Beppu Bay (Murakami). Tomioka, Amakusa (Murakami). Off Namai, Kagoshima Gulf (Clark, Matsumoto). Gulf of Thai (Koehler). Amboina (Koehler).

\section{Amphipholis japonica Matsumoto}

Matsumoto, 1915, p. 71 ; -, 1917, p. 186, fig. 49.

Locality-Shirahama, Kii, 1943 ; five specimens.

Distribution.-Misaki (Clark, Matsumoto). South Izu (Murakami). Tomo, 
Bingo (Matsumoto). Asami Bay, Tsushima (Matsumoto). Shimabara, Hizen (Matsumoto). Tomioka, Amakusa (Murakami). Akune, Satsuma (Matsumoto).

\section{Family Ophiothricidae}

\section{Ophiothrix koreana DunCAN}

DuncAN, 1879 , p. 473 , pl. XI, figs. 28-32 ; ClaRK, 1911, p. 257, figs. 127-128; Matsumoto, 1917. p. 220 , pl. IV, fig. 7 .

Locality.-Shirahama, Kii, 1943 ; one specimen.

Distribution.-Hakodate Bay (C $\left.\mathrm{C}_{\mathrm{LARK}}\right)$. Off the Pacific coast of Kazusa (Nisiyama). Gulf of Tokyo (C $\mathrm{C}_{\text {ARK }}$ ). Mouth of the Gulf of Tokyo (C $\mathrm{C}_{\mathrm{ARK}}$ ). Uraga Channel (Clark, Matsumoto). Sagami Sea (Clark, Matsumoto, MuraKami). Off Suno Saki (Clark). Off Seno Umi (CllarK). Suruga Gulf (CllarK, Murakami). Off Ose Zaki (Clark). Off Omae Zaki (Clark). Tomioka, Amakusa (Murakami). Sothwest of the Gotô Islands (Clark). Kagoshima Gulf (Clark). Off Kagoshima Gulf (C $\mathrm{C}_{\text {LARK }}$ ). Off Noma Saki (Clark). Off eastern coast (Clark). Off southern Japan (Clark). Eastern Sea (Clark). Coast of Korea (Clark). Korea Straits (Duncan, Clark). Sea of Japan (Clark). Nanao Bay (Murakami). Malaysian waters.

\section{Ophiothrix marenzelleri KOEHLER}

Ophiothrix marenzelleri: KOEHLER, 1904a, p. 103, figs. 76-78; MATSumoto, 1917, p. 220 ; Koehler, 1922, p. 248, pl. XXXIX, figs. 3-5, pl. C, fig. 4 ; Matsumoto, 1941, p. 342, fig. 8 .

Ophiothrix hylodes: CLARK, 1911, p. 263, fig. 130.

Locality.-Off Minabe, Kii, 1943 ; one specimen.

Distribution.-Japan (Kofhler). Mutsu Bay (Matsumoto). Ayukawa (Clark). Off Ayukawa (Matsumoto). Off the Pacific coast of Kazusa (Nisiyama). Kominato, Bôsyû (Matsumoto). Entrance of the Gulf of Tokyo (Matsumoto). Gulf of Tokyo (Clark). Misaki (Clark, Matsumoto). Off Zyôgashima, Sagami Sea (Matsumoto). Enoshima (Koehler). Toba, Shima (Matsumoto). Matoya Bay (Murakami). Toma, Bingo (Matsumoto). Asami Bay, Tsushima (Matsumoto). Tomioka, Amakusa (Murakami). Kagoshima Gulf (Matsumoto). China Sea (CLARK).

\section{Ophiotrichoides nereidina (LAMARCK)}

Ophiura nereidina: LAMARCK, 1816, p. 544.

Ophiothrix nereidina: Müller et Troschel, 1842, p. 115; Matsumoto, 1917, p. 224, fig. 61, 
pl. IV, fig. 6 .

Ophiotrichoides nereidina: CLARK, 1938, p. 306.

Ophiothrix cataphracta: MARTENS, 1870 , p. 259.

Locality.-Seto, Kii, 1943 ; two specimens.

Distribution.-Misaki (Matsumoto). Shimoda, Izu (Matsumoto). Tomioka, Amakusa (Murakami). Okinawa (Matsumoto). Yaéyama (Matsumoto). IndoPacific.

\section{Order CHILOPHIURIDA \\ Family Ophiuridae \\ Subfamily Ophiurinae}

\section{Stegophiura sculpta (DuNCAN)}

Ophioglypha sculpta: DUNCAN, 1879, p. 455, pl. IX, figs. 6-8, pl. XI, fig. 35.

Ophiura sculpta: CLARK, 1911, p. 73.

Stegophiura sculpta: Matsumoto, 1915, p. $79 ;-, 1917$, p. 258.

Locality.-Katsuura Bay, Kii, sand bottom, 1943; one specimen.

Distribution.-South Izu (Murakami). Southwest of the Gotô Islands (CLARK). Off Honsyû (Clark). Korea Straits (Duncan). Eastern Sea (Clark). East Indies (CLARK).

The specimen before me is rather of small size, having the disk of $2 \mathrm{~mm}$ in diameter. But it is undoubtedly a young specimen of S. sculpta, its characters being well in agreement with those of specimens from Izu.

\section{Stegophiura sladeni (DUNCAN)}

Ophioglypha sladeni: DUNCAN, 1879, p. 458, pl. IX, figs. 9-11.

Stegophiura sladeni: MATSUmoto, 1915, p. 79 ; -, 1917, p. 259, fig. 72, p1. V, fig. 6 ; KoEHLER, 1922, p. 369, pl. LXXXIII, figs. 4-7, pl. LXXXIV, fig. 1.

Ophiura stiphra: CLARK, 1911, p. 82, fig. 25.

Locality.-Off Minabe, Kii, 1943 ; one specimen.

Distribution.--Hakodate (Koehler). Off Kinkwasan (Matsumoto). Off the Pacific coast of Kazusa (Nisiyama). Uraga Channel (Matsumoto). Okinose, Sagami Sea (Matsumoto). Off Ose Zaki (Clark). Off Honsyû (Clark). Off east coast (Clark). Off Kagoshima Gulf (Clark). Korean Sea (DunCAN). Korea Straits (CLARK). Sea of Japan (CLARK).

\section{Stegophiura sterea (CLARK)}

Ophioglypha sterea: CLA.RK, 1908, p. 293.

Ophiura sterea: CLARK, 1911, p. 75, fig. 22.

Stegophiura sterea: Matsumoto, 1915, p. 79 ; -, 1917, p. 258, fig. 71. 
Locality.-Off Minabe, Kii, 1943 ; one specimen.

Distribution.--Off Kinkwasan (CLARK, MAtSumoto). Uraga Channel (C.ARK, Matsumoto). Sagami Sea (Matsumoto, Murakami). Suruga Gulf (Clark, Murakami). Off Kii (Clark). Off Honsyâ (Clark). Off east coast (Clark). Off Korea (ClaRK). Sea of Japan (C $\left.\mathrm{C}_{\text {LARK }}\right)$. Namerigawa, Ecchu (MATSUmoto). Off Ando Saki (CLARK).

The specimens from three localities are at my hand, showing rather distinct variation in their features. Those from Tsuiyama, which were collected by Dr. Y. OKADA, ex-professor of Fisheries Department, Mie Prefectural University, and range from 12 to $14 \mathrm{~mm}$ in diameter of disk, are well in accord with ClaRK's original description and figures, the contrast of true and secondary arm spines being not conspicuous. The specimen from Suruga Gulf, which bears the disk of $11 \mathrm{~mm}$ across, is similar to Matsumoto's figure in the arm spines, among which the true spines are larger and more pointed than in the foregoing, but in the other characters it does not show any distinctness. However, the specimen from off Minabe, which measures $12 \mathrm{~mm}$ scross the disk, is most different from CLARK's specimens. The true spines are very distinct and remarkably larger than the secondary ones. The tentacle scales are coarse and bluntly pointed. The radial shields are longer than broad, though they are broader than long in normal one. In these respects, the last specimen recalls $S$. steritis KOEHLER, but the characters of arm spines are quite different between them. In the specimen from off Minabe the secondary arm spines are independent from each other as those of S. sterea, while they are close and tend to form a fringe similar to that in S. sterilis. Therefore, I consider that the specimen from off Minabe is within the range of variation of S. sterea.

\section{Ophiura kinbergi (LJUNGMAN)}

Ophioglypha kinbergi: LJUNGMAN, 1866, p. 166.

Ophiura kinbergi: ClaRK, 1911, p. 37, fig. 9; MATSUMOTO, 1917, p. 271, fig. 73 ; KoEHLER, 1922 , p. 381.

Ophioglypha sinensis: LYMAN, 1871, p. 12, pl. I, figs. 1-2.

Ophioglypha ferruginea: LyMAN, 1878, p. 68, pl. III, fig. 76 .

Locality.-Yura Bay, Kii, sand bottom, 1943 ; three specimens.

Distribution.-Otaru (Koenler). Mutsu Bay (Matsumoto). Gulf of Tokyo (Clark). Off Yokohama (Lyman). Uraga Channel (Matsumoto). Misaki (Matsumoto). Enoshima (Koenler). South Izu (Murakami). Mikawa Bay (Murakami). Matoya Bay (Murakami). Wakanoura, Kiushu (Koehler) ${ }^{1}$. Inland Sea (L yman). Tomo, Bingo (Matsumoto). Beppu Bay (Murakami). Hakata Bay (Murakami). Tsushima (Matsumoto). Tomioka, Amakusa (Murakami). Off Noma Zaki

1) Probably Kisyu. 


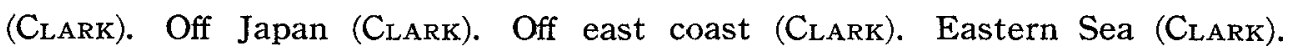
Sea of Japan (CLARK). Indo-Pacific.

\section{Subfamily Ophiolepidinae}

\section{Ophiomusium simplex LYMAN}

Ophiomusium simplex: Lyman, 1878, p. 115, pl. I, figs, 10-11; Clark, 1911, p. 109 ; Murakami, $1944 a$, p. 255.

Ophiomusium sanctum: KoEHLER, 1904b, p. 59, pl. XI, figs. 7-9.

Locality._-Off Minabe, Kii, 1943 ; one specimen.

Distribution.--Off Ogasawara (MURAKami). Eastern Sea (Clark). Southwest of the Gotô Islands (Clark). Philippine Islands (Koenler). Amboina (Lyman). Malaysian waters.

\section{Ophiomusium trychnum $\mathrm{C}_{\mathrm{LARK}}$}

Clark, 1911, p. 109, fig. 40 ; Matsumoto, 1917, p. 290, fig. 78, pl. V, fig, 7.

Locality.-Off Minabe, Kii, 1943; two specimens.

Distribution.-Off the Pacific coast of Kazusa (Nistyama). Gulf of Tokyo (Clark). Uraga Channel (Clark). Off Uraga Channel (Clark). Sagami Sea (Matsumoto). Suruga Gulf (C

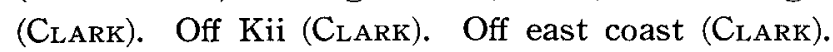

\section{Ophiozonella longispina (CLARK)}

Ophiozona longispina: CLARK, 1908, p. $290 ;-$, 1911, p. 33.

Ophiozonella longispina: MATsumoto, 1915, p. 82; CLARK, 1915, p. 338, pl. XX, figs. 5-6; Matsumoto, 1917, p. 297, fig. 80, pl. V, fig. 9.

Locality.-Off Minabe, Kii, 1943 ; two specimens.

Distribution.-Uraga Channel (ClARK). Sagami Sea (Matsumoto). Suruga Gulf (Clark, Matsumoto, Murakami). Off Ose Zaki (Clark). Off eastern Japan ( $\mathrm{C}_{\text {LARK}}$ ). Off eastern coast (CLARK).

\section{Ophioplocus japonicus $\mathrm{C}_{\mathrm{LARK}}$}

ClaRK, 1911, p. 30, fig. 5 ; Matsumoto, 1917, p. 302, fig. 84, pl. V, fig. 11.

Locality.-Satono, Kii, 1943 ; one specimen.

Distribution.-Japan (CLARK). Ayukawa (Clark). Kominato, Bôsyû (MAtsu- 
Moto). Mouth of the Gulf of Tokyo (Clark). Misaki (Clark, Matsumoto). Enoshima (Clark). Odawara (Clark). Enoura (Matsumoto). South Izu (Murakami). Tomioka, Amakusa (Murakami). Hong Kong (Mortensen).

\section{Family Ophiodermatidae}

\section{Subfamily Ophiodermatinae}

\section{Ophiarachnella gorgonia (MÜLLER et TROSCHEL)}

Ophiarachna gorgonia: MÜLLER et TROSCHEL, 1842, p. 105.

Pectinura gorgonia: LÜTKEN, 1869, p. 33.

Ophiarachnella gorgonia; CLARK, 1909, p. 123 ; MATSUMoTo, 1917, p. 323, pl. VI, fig. 7.

Pectinura marmorata: LyMAN, 1874, p. 222, pl. V, figs. 1-7.

Pectinura ramsayi: BELL, 1888a, p. 281, pl. XVI, figs. 1-2.

Pectinura intermedia: BELL, 1888 b, p. 386.

Pectinura stearnsii: IvEs, 1891, p. 212, pl. XI, figs. 1-5.

Pectinura venusta: LorIol, 1894, p. 16, pl. XXIII, figs. $3-3 \mathrm{~h}$.

Locality.-Seto, Kii, 1943 ; one specimen.

Distribution.-Japan (Ives). Misaki (Matsumoto). Enoura, Suruga (Matsumoto). South Izu (Murakami). Tomioka, Amakusa (Murakami). Kagoshima Gulf (Matsumoto). Southern Japan (Clark). Yaéyama (Murakami). IndoPacific.

\section{Family Ophiocomidae \\ Subfamily Ophiocominae}

\section{Ophiocoma brevipes PETERS}

Peters, 1851, p. 466 ; Matsumoto, 1917, p. 343, fig. 95.

Locality.-Satono, Kii, 1943 ; one specimen.

Distribution.--South Izu (Murakami). Natsui, Hyuga (Matsumoto). Tomioka, Amakusa (Murakami) ${ }^{11}$. Tanegashima (Clark). Okinawa (Matsumoto). Yaéyama (Matsumoto, Murakami). Kôsyun, Taiwan (Matsumoto). IndoPacific.

\section{Ophiomastix mixta LÜTKEN}

LÜTKEN, 1869, p. 44; Cl.A.RK, 1911, p. 256, fig. 126; MAtsumoto, 1917, p. 348, fig. 97 ; MURAKAMI, 1944b, p. 277.

1) As I collected one specimen of this species bt Tomioka, May 24, 1944, it seems to be better to add here this locality. 
Locality.-Susami, Kii, 1943 ; one specimen.

Distribution.-Gulf of Tokyo (C LARK). Misaki (MAtsumoto). Enoshima (Matsumoto). Izu (Murakami). Tomioka, Amakusa (Murakami). Tanegashima (Clark). Yaéyama (Murakami). Malaysian waters. Pacific Ocean.

\section{Subfamily Ophiopsilinae}

\section{Ophiopsila squamifera sp. nov. ${ }^{12}$}

Disk, which can not be accurately measured for its shrinkage, is roughly $6 \mathrm{~mm}$ in diameter; arms all torn away near the disk, but judging from the fragments available, more than seven times as long as the disk diameter.

Disk five-lobed, concave at the interradial border, covered with a skin

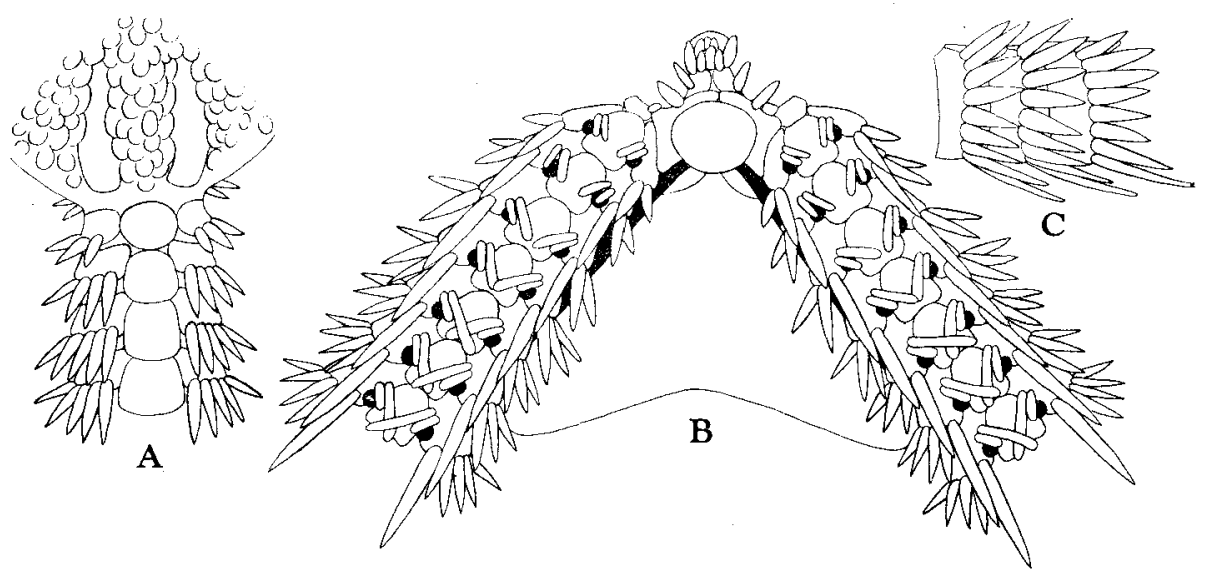

Fig. 1. Ophiopsila squamifera, sp. nov.

A. From above. B. From below. C. Side view of three arm joints near disk. $\times 11$.

containing small, delicate, rounded scales. Radial shields of small size, less than on half of disk radius in length, much elongate, about three and a half times as long as broad, somewhat enlarged distad, and bluntly pointed at the proximal end. They are well separated from each other. Interbrachial spaces below covered with a naked skin. Genital slite large, reaching from the oral shield to near the periphery of disk.

Oral shields small, elliptical, a little broader than long. Madreporite somewhat larger than the rest, roughly pentagonal in shape, with a broad proximal angle, and about as wide as long. Adoarl shields also of small size, elongate, in contact with each other at the median interradial line, curved along the

1) Squamifer, signifying scale-bearing, in reference to the disk skin containing delicate scales. 
margin of oral shield, and separating the first side arm plate from the oral shield. Oral plates indistinct. Oral papillae three in number on one side of an oral angle, among which the distal one is rudimentary; the next one is flat, lanceolate, and rather sharply pointed at the tip; the proximal one is similar to, but somewhat smaller than, the foregoing. Dental papillae from five to eight in number, small, conical. Additional two long papillae high up on the jaw. Teeth six in number on a jaw, among which the undermost two are small, with rounded free margin, while the rest are much longer than the foregoing and tetragonal in shape.

First dorsal arm plates rather small, elliptical; the succeeding ones of moderate size, tetragonal, diverging without and broader than long except those near the disk which are about as long as broad, but becoming pentagonal or rhomboidal and longer than broad at the terminal part of arm. They are broadly in contact with each other at the greater part of arm, but become separated from each other towards the extremity. First ventral arm plates very small and broader than long. Following ones pentagonal, with a proximal angle rounded, lateral and distal margin slightly concave. They are longer than broad and in contact with each other throughout the whole length of arm. Side arm plates tall and narrow, about as high as an arm joint, somewhat prominent along the distal ridge, not meeting above or below. Arm spines eight or nine in number for each arm plate near the disk, but falling to three towards the tip of arm; among them the undermost one is the largest and more or less twice as long as a joint, but they become reduced in length as they proceed towards the middle where they are almost as long as a joint; from the seventh above they again increase in length, but the uppermost one is by no means larger than the preceding to it. They are flat and bluntly pointed at the tip, among which the upper two or three are flattest and broadest. Tentacle scales two for each pore, distinct, flat, elongate, but blunt at the end the abradial one is smaller than the adradial one which is at first less than a joint in length, but soon becomes longer than it and reaches about one and a half times as long as a joint at the middle part of arm; farther out it again diminishes in length.

Colour (dried from formalin), disk brownish black, except the radial shields which are light brown; dorsal side of arm dark brown, with a band of dark shade each six or seven joints; mouth parts and ventral side of arm light brown; arm spines brownish.

Locality.-Hôza Bay, Ise, 1943 ; one specimen.

The specimen at hand is not in good state of preservation, but I consider that it belongs to a new form for its distinct characters. The new species bears a close resemblance to $O$. vittata $C_{\text {LARK, }}$ but the oral shields of the former are elliptical, while in the latter they are diamond-shaped. The disk of $O$. 
squamifera is covered with a skin containing delicate scales, but in 0 . vittata it bears no any such scales. The oral papillae of $O$. vittata are four in number, but in $O$. squamifera they are three. It is also nearly related to $O$. pantherina KoEHLER, but the mouth parts are quite different between them. Moreover, in $O$. squamifera the oral shields are elliptical in shape, the adoral shields are producing a narrow lobe at the distal end so as to separate the first side arm plate from the oral shield, and the oral papillae are long and narrow except the distal one, but in $O$. pantherina the oral shields are oval or piriform in shape, the adoral shields do not protrude a distal lobe, and the oral papilae are broad and short. Further, the arm spines of $O$. squamifera are eight or nine in number, while they are seven in $O$. pantherina. The new species also recalls o. polyacantha $\mathrm{C}_{\mathrm{LARK}}$, but the number of arm spines of the latter is more than those of the former, being ten or eleven. Moreover, the mouth parts of $O$. polyacantha are rather similar to those of $O$, pantherina.

\section{LITERATURE}

BelL, F. J. 1888a. Descriptions of four new species of Ophiurids. Proc. Zool. Soc., 1888, London. 1888b. Report on a collection of Echinoderms made at Tuticorin, Madras, by $\mathrm{Mr}$.

Edgar Thurston, C. M. Z. S., Superintendent, Government Central Museum, Madrs. Ditto.

Brock, J. 1888. Die Ophiuridenfauna des indischen Archipels. Zeit. f. wiss. Zool., XLVII, 3.

Clark, H. L. 1908. Some Japanese and East Indian Echinoderms. Bull. Mus. Comp. Zoöl., LI, 11. 1909. Notes on some Australian and Indo-Pacific Echinoderms. Ditto, LII, 7.

1911. North Pacific Ophiurans in the collection of the United States National

Museum. U. S. Nat. Mus., Bull. 75.

1915. Catalogue of recent Ophiurans: based on the collection of the Museum of

Comparative Zoöl., XXV, 4.

1918. Brittle-stars, new and old. Bull. Mus. Comp. Zoöl., LXII, 6.

1938. Echinoderms from Australia. Mem. Mus. Comp. Zoöl., LV.

Döderlein, L. 1896. Bericht über die von Herrn Professor Semon bei Amboina und Thursday Island gesammelten Ophiuroidea. Semon-Zool, Forschungsr., V.

DunCAN, P. M. 1879. On some Ophiuroidea from the Korean Seas, Journ. Linn. Soc., Zool., XIV.

FELL, H. B. 1962. A revision of the major genera of Amphiurid Ophiuroidea. Trans. Roy. Soc. N. Z., Zool., II, 2.

Grube, E. 1857. Diagnosen einiger neuen Echinodermen. Arch. Naturg,, I.

IvEs, J. E. 1891. Echinoderms and Arthropods from Japan. Proc. Acad. Nat. Sci. Philadelphia, 1891.

Koehler, R. 1904a. Ophiures nouvelles ou peu connues. Mém. Soc. Zool. France, XVII.

Leiden. 1904b. Ophiures de l'Expedition du Siboga. Pt. I. Ophiures de mer profonde. $100, \mathrm{~V}$. 1922. Ophiurans of the Philippine Seas and adjacent waters. U. S. Nat. Mus., Bull. 1930. Papers from Dr. Th. Mortensen's Pacific Expedition 1914-16. LIV. Ophiures recueillies par le Docteur Th. Mortensen dans les Mers d'Australie at dans I'Archipel Malais. Vidensk. Medd. fra Dansk naturh. Foren., LXXXIX.

LAMARCK, J. B. P. 1816. Histoire Naturelle des Animaux sans Vertèbres. II.

LJUNGMAN, A. 1866. Om några nya arter af Ophiurider. Öfv. Kongl. vet.-akad. Förh., 6. 
Förh., XXIII, 9.

LorIol, P. de 1893. Echinodermes de la Baie d'Amboine. Rev. Suisse Zool., I.

1894. Catalogue raisonné des Échinodermes recueillis par M. de Robillard à l'ile

Maurice. III, Ophiuridés et Astrophytidés. Mém. Soc. Phys. et Hist. Nat., Genève, XXXII, 1.

LÜTKEN, Ch. 1856. Bidrag til Kundskab om Slangestjernerne. II. Oversigt over de vestindiske

Ophiurer. III, Bidrag til Kundskab om Ophiurene ved Central-Amerikas Vestkyst. Naturh.

Foren. Vidensk. Meddelelser.

1859. Additamenta ad historiam Ophiuridarum. II.

1869. Ditto. III.

LÜTKEN, Ch. and Th. Mortensen 1899. Reports on an exploration...by the Steamer "Albatross". XXV. The Ophiuridae. Mem. Mus. Comp. Zoöl., XXIII, 2.

Lyman, Th. 1871. Supplement to the Ophiuridae and Astrophytidae. Ill. Cat. Mus. Zoöl., 6.

1874. Ophiuridae and Astrophytidae, new and old. Bull. Mus. Comp. Zoöl., III, 10.

1878. Ophiuridae and Astrophytidae of the exploring voyage of H. M. S. "Chal-

lenger". Part I. Bull. Mus. Comp. Zoöl., V, 7.

1882. Report on the Ophiuroidea dredged by the Challenger. The Voyage of the

Challenger, Zool., V.

Martens, E. v. 1870. Die Ophiuriden des indischen Oceans, Arch. Naturg., XXXVI.

Matsumoto, H. 1915. A new classification of the Ophiuroidea : with descriptions of new genera and species. Proc. Acad. Nat. Sci., Philadelphia, LXVIr.

1917. A monograph of Japanese Ophiuroidea, arranged according to a new classification. Journ. Coll. Sci., Imp. Univ. Tokyo, XXXVIII, 2.

1918. On a collection of Ophiurans from the vicinity of Kinkwasan, with descri-

ption of a new species. Annot. Zool. Japon., IX. 4.

1941. Report of the biological survey of Mutsu Bay. 36. Ophiuroidea of the Mutsu

Bay and vicinities. Sci. Rep. Tohoku Imp. Univ., Fourth Series, Biol., XVI, 3.

Mortensen, Th. 1924. Papers from Dr. Th. Mortensen's Pacific Expedition 1914-16. XX. Echinoderms of New Zealand and the Auckland-Campbell Islands. II. Ophiuroidea. Vidensk. Medd. fra Dansk naturh. Foren., LXXVII.

1934. Echinoderms of Hong Kong. Hong Kong Nat. Suppl., 3.

Müller, J. und F. Troschel 1842. System der Asteriden.

MuraKami, S. 1942. Ophiurans of Izu, Japan. Journ. Dept. Agric., Kyusyu Imp. Univ. VII, 1.

1943a. Report on the Ophiurans of Palao, Caroline Islands. Ditto, VII, 4.

1943b. Report on the Ophiurans of Yaéyama. Ryukyu. Ditto, VII, 5.

1943c. Ophiurans from gulfs and bays of Nippon. Ditto, VII, 6.

1944a. Report on the Ophiurans from off Ogasawara Islands and from off the

Yaéyama Group, Nippon. Ditto, VII, 7.

1944b. Note on the Ophiurans of Amakusa, Kyusyu. Ditto, VII, 8.

NisiYAmA, S. 1937. Annotated list of the Ophiurans dredged from the Pacific coast of Tiba Prefecture. Rec. Ocean. Wk. Jap., IX, 1.

Peters, W. K. H. 1851. Übersicht der von ihm an der Küste von Mossambique eingesammelten Ophiuren, unter denen sich zwei neue Gattungen befinden. Monatsb. König. Preuss. Akad. Wiss., Berlin. 